\title{
STUDI KASUS: LITERASI MATEMATIS SISWA BERDASARKAN GAYA BELAJAR KOLB DI SMPN 21 SURABAYA
}

\author{
Anis Norawati \\ Pendidikan Matematika, Fakultas Pendidikan Matematika dan Ilmu Pengetahuan Alam, Universitas Negeri Surabaya \\ E-mail: anisnorawati@mhs.unesa.ac.id
}

\begin{abstract}
Abstrak
Literasi matematis merupakan kecakapan individu dalam merumuskan, menerapkan, dan menafsirkan matematika ke dalam berbagai konteks. Literasi matematis setiap siswa dapat dipengaruhi oleh salah satu faktor internal yaitu gaya belajar Kolb. Gaya belajar Kolb terdiri dari empat macam, yaitu akomodasi, divergen, asimilasi, dan konvergen. Penelitian ini merupakan penelitian deskriptif-kualitatif dengan tujuan mendeskripsikan literasi matematis siswa dalam menyelesaikan soal PISA pada konten space and shape berdasarkan gaya belajar Kolb. Teknik pengambilan data ini dengan angket, tes dan wawancara. Subjek penelitian terdiri dari empat siswa yang masing-masing memiliki gaya belajar akomodasi, divergen, asimilasi, dan konvergen. Hasil penelitian menunjukkan bahwa: (1) Siswa akomodasi melalui proses mengidentifikasi aspek penting dari permasalahan, menerjemahkan masalah ke dalam bahasa matematika, menggunakan konsep matematika dan perkiraan untuk menemukan solusi, menafsirkan kembali hasil perhitungannya tetapi tidak melakukan evaluasi kembali. (2) Siswa divergen melalui proses mengidentifikasi aspek matematika yang penting dari soal, kurang tepat dalam menerjemahkan masalah ke dalam bahasa matematika, merencanakan dan menerapkan strategi menggunakan percobaan langsung, menafsirkan kembali hasil perhitungannya dan tidak mengevaluasi kembali. (3) Siswa asimilasi melalui proses mengidentifikasi aspek penting dari soal, menerjemahkan ke bahasa matematika dengan jelas, menggunakan konsep matematika dan menuliskan tahap demi tahap, menafsirkan kembali hasil perhitungannya dan mengevaluasi kembali. (4) Siswa konvergen melalui proses mengidentifikasi aspek-aspek penting dalam permasalahan soal, kurang tepat dalam menerjemahkan ke dalam bahasa matematika, menggunakan konsep matematika dan percobaan langsung untuk menemukan solusi, menafsirkan kembali hasilnya dan tidak melakukan evaluasi kesesuaian jawaban.
\end{abstract}

Kata Kunci: literasi matematis, konten space and shape, gaya belajar Kolb

\section{Abstract}

Mathematical literacy is an individual's capacity to formulate, employ, and interpret mathematics in a variety of contexts. Mathematical literacy of each students can influenced by one internal factor, namely Kolb's learning style. Kolb's learning style consists of accomodating, diverging, assimilating, and converging. The research is a qualitative-descriptive reseacrh that aims to describe mathematical literacy students in PISA questioan solving on the content space and shape based on Kolb's learning style. This research technique used questionnaire, test, and interview. The research subject were four students, each of had accomodating, diverging, assimilating, and converging learning style. The results of this research shows that (1) Students accmodating through the process of identifying important aspect of promblems, translating promblems into mathematical language, using mathematical cocepts and estimates to find solution, reinterpreting the result of calculations but not re-evaluating the solution. (2) Students diverging through the process of identifying important aspect of the problem, incorrectly translating problems into mathematical language, planning and implementing strategies using direct experiments, reinterpreting the result of calcualtions and not reevaluating the solution. (3) Students assimilating through the process of identifying aspects of the problems, translating into mathematical language clearly, using mathematical consepts and writing step by step, reinterpreting the result of calculations, and re-evaluating the solution. (4) Student converging through the process of identying important aspect of the problems, not quite right in translating into mathematical language, using mathematical concepts and direct experiments to find solutions, reinterpreting the result and not re-evaluating the solution.

Keywords: mathematical literacy, space and shape content, Kolb's learning style

\section{PENDAHULUAN}

Minat baca masyarakat Indonesia yang masih rendah mendorong pemerintah Indonesia melalui bidang pendidikan dengan membuat sebuah gerakan di sekolah yaitu Gerakan Literasi Sekolah (GLS) untuk menumbuhkan minat baca siswa. Menurut Permendikbud 
No. 23 Tahun 2015, gerakan ini dilakukan untuk menumbuhkan minat baca melalui kegiatan 15 menit membaca, meningkatkan kemampuan literasi melalui kegiatan menanggapi buku pengayaan, dan meningkatkan literasi di semua mata pelajaran. Pentingnya literasi merupakan salah satu tujuan pendidikan Indonesia. Literasi merupakan kumpulan keterampilan membaca, menulis, berbicara, berhitung, dan keterampilan yang memungkinkan untuk mengakses pengetahuan dan informasi (UNESCO, 2006). Sementara Gee (dalam Wilson, 2015:5) menginterpretasikan literasi sebagai kontrol kedua dari penggunaan bahasa. Literasi sangat penting dan bermanfaat bagi masyarakat. Hal ini sesuai dengan The National Adult Literacy Survey (OECD, 2005) mengatakan bahwa literasi berguna untuk mengembangkan pengetahuan dan potensial yang bermanfaat bagi masyarakat. Dengan literasi maka seseorang dapat bersaing secara global karena memiliki keterampilan-keterampilan tersebut.

Kemampuan literasi menjadi hal-hal yang perlu dalam memahami matematika. Pencapaian literasi siswa Indonesia dapat dilihat dari hasil TIMSS (Trends in International Mathematics and Science Study) dan PISA (Programme for International Stucent Assesment). Hasil studi TIMSS digunakan untuk mengetahui perkembangan matematika dan ilmu pengetahuan alam siswa usia 13 tahun. Sedangkan PISA digunakan untuk mengetahui perkembangan literasi ilmu pengetahuan alam, membaca, dan matematika siswa usia 15 tahun. Berdasarkan hasil studi TIMSS dan PISA tersebut, literasi tidak hanya membaca saja tetapi juga dapat diketahui dari literasi matematis. Hasil PISA 2015 menyatakan bahwa skor literasi matematis siswa Indonesia masih rendah yaitu 386, di bawah rata-rata OECD 490 (OECD, 2015).

Dalam Draft PISA 2015 Mathematics Framework, literasi matematis didefinisikan oleh OECD (2013b: 5) sebagai berikut.

Mathematical literacy is an individual's capacity to formulate, employ, and interpret mathematics in a variety of contexts. It include reasoning mathematically and using mathematical concepts, procedures, fact and tool to describe, explain and a predict phenomena. It assist individuals to recognize the role that mathematics plays in the world and to make the well-founded judgments and decisions need by constructive, engaged and reflective citizens.

Berdasarkan definisi di atas, literasi matematis merupakan keterlibatan aktif individu dalam merumuskan, menerapkan dan menafsirkan matematika dalam berbagai konteks. Literasi matematis mencakup penalaran matematika menggunakan konsep, prosedur, fakta, dan alat matematika untuk mendeskripsikan, menjelaskan dan memprediksi peristiwa. Maksud dari alat matematika dalam OECD adalah perangkat yang digunakan untuk membantu siswa menyelesaikan masalah seperti menggunakan penggaris, jangka, busur, kalkulator dan komputer.

Literasi matematis membantu seseorang memahami peran atau kegunaan matematika dalam kehidupan seharihari dengan menggunakan penalarannya. OECD (2013a) menjelaskan bahwa penilaian literasi matematis pada PISA terdiri dari 3 kategori, yaitu konten, proses, dan konteks. Materi yang diujikan dalam literasi matematis pada soal PISA terdiri dari empat konten, yaitu change and relationship (perubahan dan keterkaitan), space and shape (ruang dan bentuk), quantity (kuantitas), dan uncertainty and data (ketidakpastian dan data). Proses literasi matematis terdiri dari merumuskan (formulate), menerapkan (employ), dan menafsirkan (interpret). Konteks pada literasi matematis terdiri dari pribadi, pekerjaan, sosial, dan pengetahuan. Salah satu konten soal PISA adalah space and shape. OECD (2013b) menyatakan bahwa soal konten space and shape berkaitan dengan kemampuan penerapan konsep, fakta, prosedur, dan penalaran matematika yang berhubungan dengan ruang dan bentuk geometri dalam kehidupan sehari-hari. Pemahaman ruang dan bentuk ini bermanfaat dalam kehidupan seharihari. OECD (2014) menyatakan terdapat tujuh kecakapan dasar yang digunakan pada literasi matematis dalam soal PISA yaitu (1) komunikasi, (2) matematisasi, (3) representasi, (4) penalaran dan argumen, (5) membagi strategi untuk penyelesaian masalah, (6) menggunakan simbol, formal, bahasa dan operasi teknis, dan (7) menggunakan alat matematis. Kategori konten space and shape melebihi aspek konten geometri pada matematika yang ada dalam kurikulum (Johar, 2012). Dari hasil analisis Purnomo dan Dafik (2015) tentang respon siswa SMP kelas VIII terhadap soal PISA konten space and shape menunjukkan bahwa sebagian besar siswa setuju jika soalsoal tipe PISA diberikan untuk melatih penalaran, siswa tertarik dengan tipe soal-soal PISA, dan siswa merasa tertantang mengerjakan tipe soal PISA.

Mahdiansyah dan Rahmawati (2014) menjelaskan faktor-faktor yang mempengaruhi literasi matematis siswa yaitu faktor internal (faktor dari dalam diri siswa) dan faktor eksternal (faktor dari luar siswa). Wardhani (2016) juga menjelaskan faktor internal yang mempengaruhi literasi matematis yaitu psikologis, tingkat kecerdasan, gaya belajar dan perkembangan kognitif. Syawahid (2017) menyatakan bahwa terdapat perbedaan kemampuan literasi matematika ditinjau dari gaya belajar. Dari penjelasan tersebut maka gaya belajar merupakan salah satu faktor yang memengaruhi literasi matematis siswa. Gaya belajar memiliki definisi yang berbeda-beda menurut pandangan para ahli. Hartley (Casidy, 2004:421) mendefinisikan gaya belajar adalah cara individu dalam melakukan pendekatan 
perbedaan tugas belajar. Zolghadri dkk (2015) menyatakan gaya belajar didefinisikan sebagai cara seseorang berpikir atau melihat dunia. Sedangkan Ghufron (2012:42) mendefinisikan "gaya belajar merupakan sebuah pendekatan yang menjelaskan bagaimana seseorang siswa belajar atau cara yang ditempuh oleh masing-masing siswa untuk berkonsentrasi pada proses dan menguasai informasi yang sulit dan baru melalui persepsi yang berbeda". Kolb (2005:6) juga mendefinisikan gaya belajar sebagai konsep psikologi sosial yang hanya sebagian ditentukan oleh kepribadian. Berdasarkan pernyataan di atas disimpulkan bahwa gaya belajar adalah cara yang dilakukan individu untuk mendapatkan informasi dengan memilih strategi yang paling tepat agar informasi yang diperoleh dapat tersimpan dengan baik.

Tipe gaya belajar berbeda-beda menurut pandangan para ahli, salah satunya tipe gaya belajar Kolb. Gaya belajar Kolb dikembangkan oleh David Kolb melalui Experiental Learning Theory. Kolb (2005) menyatakan belajar merupakan suatu lingkaran yang dimulai dari pengalaman konkret (concret experience), diikuti refleksi (reflective observation/ observasi reflektif) yang menghasilkan konsep abstrak (abstract conseptualization), yang selanjutnya melakukan tindakan (active experiment). Kolb berpendapat bahwa tidak semua individu dominan di keempat pengalaman tersebut. Kolb (2005: 4) menyatakan terdapat empat gaya belajar yang merupakan kombinasi dari empat pengalaman di atas, yaitu akomodasi, divergen, asimilasi, dan konvergen. Gaya belajar akomodasi adalah gaya belajar yang melibatkan pengalaman konkret dan eksperimen aktif. Siswa dengan gaya belajar akomodasi lebih suka bekerja dengan orang lain untuk menyelesaikan tugasnya, mencapai tujuan dan melengkapi proyeknya. Divergen adalah gaya belajar yang melibatkan pengalaman konkrit dan observasi reflektif. Siswa dengan gaya belajar divergen tertarik melihat situasi konkrit dari banyak sudut pandang yang berbeda untuk mendapatkan informasi. Asimilasi adalah gaya belajar yang melibatkan konseptualisasi abstrak dan observasi reflektif. Siswa dengan gaya belajar asimilasi lebih tertarik dengan ide konsep abstrak dan kurang tertarik berinteraksi dengan orang. Siswa dengan gaya belajar ini lebih suka membaca, ceramah, eksplorasi analisis model dan mempunyai waktu untuk memikirkan sesuatu. Konvergen adalah gaya belajar yang melibatkan konseptualisasi abstrak dan eksperimen aktif. Siswa dengan gaya belajar konvergen lebih suka bereksperimen dengan ide baru, simulasi, tugas laboratorium, dan penerapan praktik.

Gaya belajar Kolb merupakan gaya belajar yang paling bisa diterapkan dalam pembelajaran matematika terutama dalam memecahkan masalah (Knisley, 2002). Knisley (2002) menyatakan bahwa siswa akomodasi suka terlibat langsung pada situasi konkrit dan menyelesaikan masalah dengan menebak (kira-kira), siswa divergen memiliki kemampuan berimajinasi dan kreatif dalam menghubungkan informasi dengan informasi yang lain, siswa asimilasi menganalisis sesuatu yang abstrak, menyelesaikan masalah tahap demi tahap dan menyimpulkan pada akhir penyelesaian, dan siswa konvergen menggunakan teori dalam membuat keputusan dan menyelesaikan masalah dengan mengembangkan strategi dan pendekatan baru. Hertiandito (2016) mengatakan bahwa model pembelajaran Knisley dinilai dapat mendukung upaya siswa dan guru untuk meningkatkan kemampuan literasi matematika. Pada penelitian ini dipilih gaya belajar Kolb karena pada literasi matematis seseorang akan melakukan pemecahan masalah. Penelitian Zulfidah (2015) tentang proses pemecahan masalah matematika berdasarkan gaya belajar Kolb menyatakan terdapat perbedaan pemecahan masalah matematika untuk setiap siswa yang memiliki gaya belajar berbeda. Sedangkan menurut Fatkhiyyyah (2019) terdapat perbedaan kemampuan komunikasi matematika siswa yang signifikan antara gaya belajar divergen, assimilasi, konvergen, dan akomodasi. Dengan adanya penelitian literasi matematis siswa dalam menyelesaikan soal PISA pada konten space and shape diharapkan terdapat perbedaan literasi matematis di setiap gaya belajar siswa. Dari perbedaan literasi matematis pada setiap gaya belajar Kolb, dapat digunakan acuan oleh guru sekolah dalam memberikan soal literasi matematis sesuai gaya belajar siswa.

Berdasarkan penjelasan di atas, tujuan dari penelitian ini adalah untuk mendeskripsikan literasi matematis siswa dengan gaya belajar akomodasi, divergen, asimilasi, dan konvergen dalam menyelesaikan soal PISA pada konten space and shape.

\section{METODE}

Penelitian ini bertujuan mendeskripsikan literasi matematis siswa dalam menyelesaikan soal PISA pada konten space and shape berdasarkan gaya belajar Kolb. Berdasarkan tujuan tersebut, maka jenis penelitian ini merupakan penelitian deskriptif dengan pendekatan kualitatif. Instrumen yang digunakan ada 2 macam, yaitu instrumen utama adalah peneliti sendiri, dan instrumen pendukung yang terdiri dari angket gaya belajar Kolb, Tes Literasi Matematis (TLM), dan pedoman wawancara. Rancangan penelitian yang dilakukan yaitu, menyusun instrumen penelitian yang dikonsultasikan ke pembimbing, melakukan validasi instrumen, mengambil data, menganalisis data, dan menyusun laporan penelitian.

Penelitian ini dilakukan pada siswa kelas IX SMP Negeri 21 Surabaya yang diikuti oleh 30 siswa. Sumber data penelitian berasal dari subjek penelitian yang terdiri dari 4 siswa dengan gaya belajar Kolb berbeda, yaitu satu 
siswa dengan gaya belajar akomodasi, satu siswa dengan gaya belajar divergen, satu siswa dengan gaya belajar aslimiasi, dan satu siswa dengan gaya belajar konvergen. Penentuan subjek ditentukan dari hasil angket gaya belajar Kolb yang sudah dikelompokkan, kemudian siswa diberikan Tes Literasi Matematika. Dari hasil TLM dipilih siswa yang memiliki skor TLM dan jenis kelamin sama pada masing-masing kelompok gaya belajar untuk kemudian dianalisis proses literasi matematisnya.

Teknik pengumpulan data menggunakan angket, tes dan wawancara. Angket gaya belajar Kolb yang digunakan berasal dari hasil adopsi angket gaya belajar HoneyMumford (Honey, 2006) yang terdiri dari 80 pernyataan. Metode tes yang digunakan berasal dari Tes Literasi Matematis (TLM) yang terdiri 2 soal PISA. Metode wawancara dilakukan kepada empat subjek terpilih setelah mengerjakan Tes Literasi Matematis. Wawancara digunakan untuk melengkapi data proses literasi matematis siswa dalam menyelesaikan soal PISA yang belum terlihat dari tes tulis.

Analisis data yang dilakukan pada penelitian ini yaitu analisis angket gaya belajar Kolb, analisis Tes Literasi Matematis, dan analisis data hasil tes wawancara. Analisis angket gaya belajar Kolb dilakukan untuk menentukan kecenderungan gaya belajar siswa dengan setiap pernyataan mewakili satu tipe gaya belajar Kolb, sehingga setiap tipe gaya belajar diwakili 20 pernyataan. Siswa yang memiliki skor tertinggi pada salah satu gaya belajar dikelompokkan sesuai gaya belajar tersebut. Analisis Tes Literasi Matematis menggunakan indikator literasi matematis sebagai berikut.

Tabel 1. Indikator Proses Literasi Matematis

\begin{tabular}{|l|l|}
\hline $\begin{array}{c}\text { Proses Literasi } \\
\text { Matematis }\end{array}$ & \multicolumn{1}{|c|}{ Indikator } \\
\hline $\begin{array}{l}\text { Merumuskan } \\
\text { Formulate })\end{array}$ & $\begin{array}{l}\text { 1. Mengidentifikasi aspek matematika } \\
\text { dan variabel yang penting dari } \\
\text { permasalahan konteks. }\end{array}$ \\
& $\begin{array}{l}\text { 2. Menerjemahkan masalah ke dalam } \\
\text { bahasa matematika } \\
\text { representasinya. }\end{array}$ \\
\hline $\begin{array}{l}\text { Menerapkan } \\
\text { (Employ) }\end{array}$ & $\begin{array}{l}\text { 1. Merencanakan dan menerapkan } \\
\text { strategi untuk menemukan solusi } \\
\text { matematis. }\end{array}$ \\
& $\begin{array}{l}\text { 2. Menggunakan fakta, menerapkan } \\
\text { aturan, algoritma dan struktur } \\
\text { matematis untuk menemukan } \\
\text { solusi. }\end{array}$ \\
\hline $\begin{array}{l}\text { Menafsirkan } \\
\text { (Interpret) }\end{array}$ & $\begin{array}{l}\text { Menafsirkan kembali hasil } \\
\text { awal. }\end{array}$ \\
\hline
\end{tabular}

2. Mengevalusi kesesuaian solusi matematis dalam permasalahan awal.

Data literasi matematis yang belum terlihat dari TLM kemudian dilakukan wawancara kepada setiap subjek. Analisis data hasil wawancara dilakukan berdasarkan pada analisis data kualitatif yaitu reduksi data, penyajian data, dan penarikan kesimpulan (Sugiyono, 2009).

\section{HASIL DAN PEMBAHASAN}

Angket gaya belajar Kolb diisi oleh 30 siswa dengan hasil 3 siswa memiliki gaya belajar akomodasi, 15 siswa memiliki gaya belajar divergen, 4 siswa memiliki gaya belajar asimilasi, 4 siswa dengan gaya belajar konvergen, dan 4 siswa dengan gaya belajar ganda. Dari 26 siswa yang telah dikelompokkan dalam gaya belajarnya, dilanjutkan untuk mengerjakan Tes Literasi Matematis (TLM) yang berisi soal PISA. Berikut ini adalah soal TLM yang digunakan pada penelitian ini.

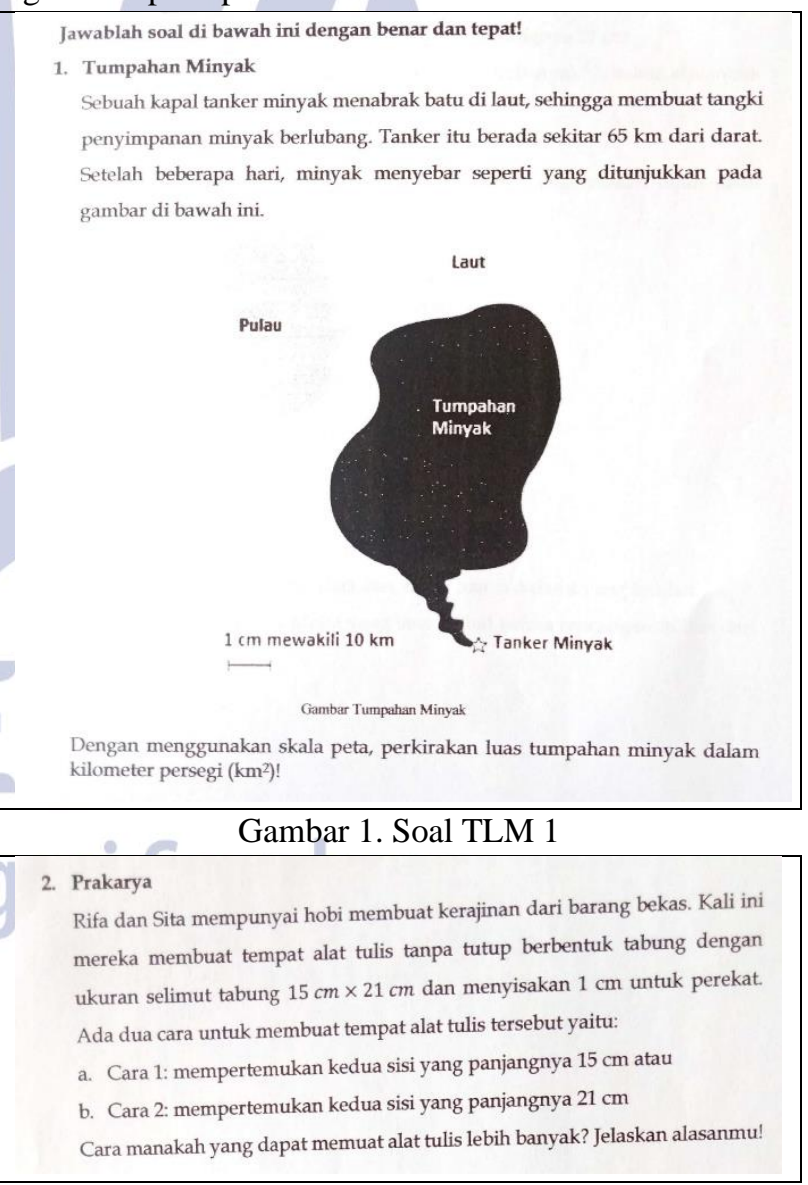

Gambar 2. Soal TLM 2

Soal TLM1 mendeskripsikan tentang perkiraan luas wilayah yang tidak beraturan pada peta menggunakan skala yang diberikan. Soal TLM2 mendeskripsikan perbandingan volume dua benda berbentuk tabung dengan ukuran tertentu. Berdasarkan hasil TLM dipilih masingmasing 1 siswa dari kelompok gaya belajarnya yang 
memiliki skor TLM dan jenis kelamin sama untuk selajutnya dianalisis proses literasi matematis siswa tersebut. Subjek penelitian yang terpilih kemudian diberikan wawancara untuk menggali proses literasi matematis yang belum terlihat dari Tes Literasi Matematis (TLM).

Berdasarkan analisis data Tes Literasi Matematis dan wawancara terhadap siswa akomodasi, siswa divergen, siswa asimilasi, dan siswa konvergen diperoleh deskripsi literasi matematis siswa dalam menyelesaikan soal PISA sebagai berikut.

1. Literasi Matematis Siswa Akomodasi dalam Menyelesaikan Soal PISA Konten Space and Shape

Berikut ini adalah hasil jawaban siswa akomodasi dalam menyelesaikan soal Tes Literasi Matematis.

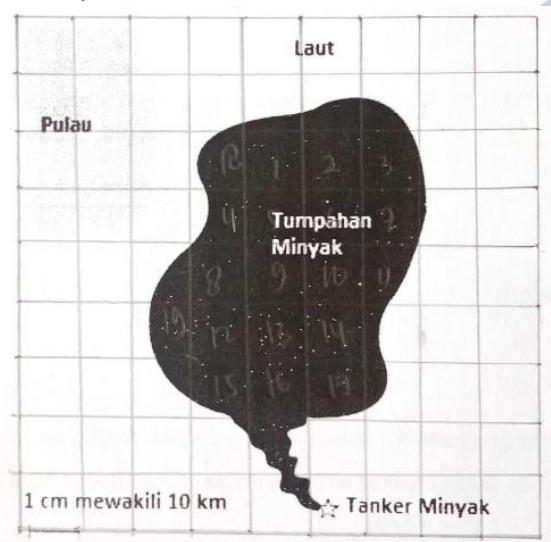

Gambar 3. Jawaban No 1 Siswa Akomodasi

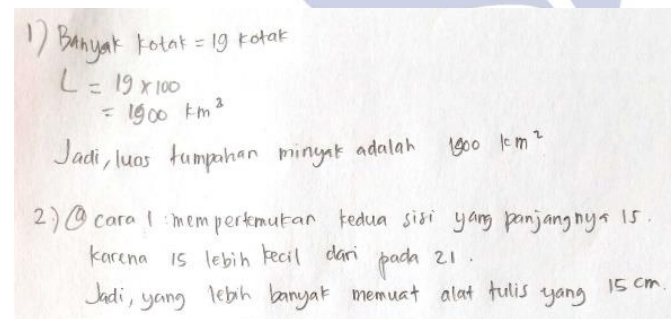

Gambar 4. Jawaban No 2 Siswa Akomodasi

Pada proses merumuskan (formulate), siswa akomodasi mengidentifikasi aspek matematika dan variabel yang penting dari/permasalahan dengan menyebutkan informasi-informasi yang penting. Siswa akomodasi menyebutkan informasi tersebut ketika wawancara karena tidak menuliskan apa yang diketahuinya pada lembar jawaban. Siswa akomodasi memahami dan menjelaskan hubungan soal TLM-1 dengan luas benda tidak beraturan, kemudian menerjemahkan masalah tersebut dengan membuat kotak-kotak persegi di atas gambar luas tumpahan minyak. Namun pada soal TLM-2, siswa akomodasi tidak dapat menjelaskan hubungan soal dengan matematika sehingga tidak dapat menerjemahkan masalah ke dalam matematika.
Pada proses menerapkan (employ) soal TLM-1, siswa akomodasi merencanakan dan menerapkan strategi untuk menemukan solusi dengan membuat kotak-kotak persegi di atasnya. Siswa akomodasi menggunakan aturan untuk menentukan luas bangun tidak beraturan dengan cara menulisi pada bagian persegi utuh untuk menghitung banyaknya persegi utuh pada daerah tumpahan minyak dan menggabungkan persegi-persegi yang tidak utuh menjadi satu bagian selanjutnya dijumlahkan. Siswa akomodasi melakukan ini karena sebelumnya pernah mengerjakan soal yang berhubungan dengan luas benda tidak beraturan. Hal ini sejalan dengan penyataan Kolb (2005) bahwa gaya belajar akomodasi melibatkan pengalaman konkrit. Sedangkan pada soal TLM-2, siswa akomodasi tidak merencanakan dan menerapkan strategi yang digunakan untuk menemukan solusi tetapi menggunakan perkiraan serta menyebutkan alasannya. Hal ini sesuai dengan pendapat Knisley (2002) bahwa siswa akomodasi menyelesaikan masalah dengan kirakira.

Pada proses menafsirkan (interpret) soal TLM-1 dan soal TLM-2, siswa akomodasi menafsirkan kembali hasil perhitungannya ke dalam permasalahan awal dengan menuliskan kesimpulan akhir dari penyelesaiannya. Siswa akomodasi tidak mengevaluasi kembali solusi yang ditemukan dalam permasalahan awal karena sudah yakin bahwa jawabannya sesuai dengan permasalahan awal.

2. Literasi Matematis Siswa Divergen dalam Menyelesaikan Soal PISA Konten Space and Shape

Berikut ini adalah hasil jawaban siswa divergen dalam menyelesaikan soal Tes Literasi Matematis.

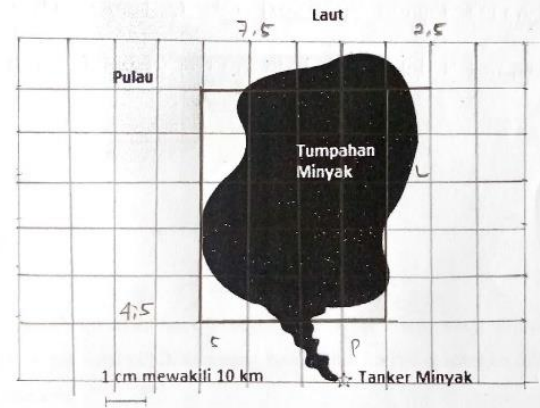

Gambar 5. Jawaban No 1 Siswa Divergen

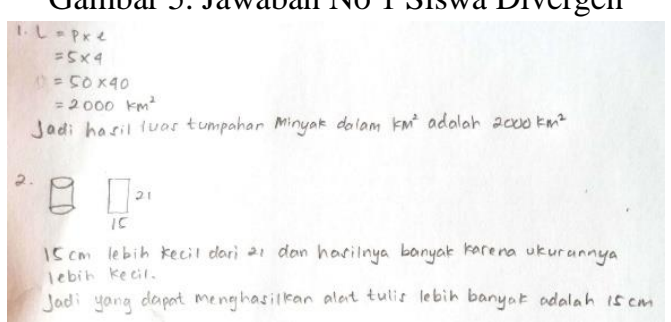

Gambar 6. Jawaban No 2 Siswa Divergen

Pada proses merumuskan (formlute), siswa divergen mengidentifikasi aspek matematika dan 
variabel penting dengan menyebutkan informasiinformasi yang terdapat pada soal TLM-1 dan TLM-2. Siswa divergen menyebutkan informasi tersebut ketika wawancara karena siswa divergen tidak menuliskan yang diketahuinya pada lembar jawaban. Pada soal TLM-1, siswa divergen menerjemahkan masalah ke dalam bahasa matematika dengan menggunakan pendekatan luas persegi panjang padahal bentuk daerah yang ditanyakan bukan persegi panjang. Pada soal TLM-2, siswa divergen tidak menerjemahkan masalah ke dalam bahasa matematika tetapi merepresentasikan dengan menggambar bentuk tabung dan persegi panjang.

Pada proses menerapkan (employ) soal TLM-1, siswa divergen merencanakan dan menerapkan strategi yang digunakan dengan membuat kotak-kotak persegi di atas daerah tumpahan minyak kemudian membuat persegi panjang yang mengelilingi daerah tumpahan minyak tersebut. Bagian tumpahan yang berada di luar persegi panjang, siswa divergen masukkan ke dalam persegi panjang tersebut sehingga luas yang digunakan mendekati bentuk pesergi panjang. Selanjutnya siswa divergen menghitung luas tumpahan minyak menggunakan luas persegi panjang. Pada soal TLM-2, siswa divergen merencanakan dan menerapkan strategi yang disebutkan dengan praktik langsung memakai kertas yang sesuai ukuran pada soal TLM-2. Hal ini siswa divergen lakukan dengan menghubungkan informasi yang ada pada soal untuk dilakukan secara langsung. Siswa divergen menggunakan fakta yang diperoleh dari hasil praktik yang dilakukan untuk menemukan solusi.

Pada proses menafsirkan (interpret) soal TLM-1, siswa divergen menafsirkan kembali hasil perhitungannya ke permasalahan awal dengan menuliskan kesimpulan akhir yang diperoleh meskipun pendekatan penyelesaiannya kurang tepat, dan tidak mengevaluasi solusi yang didapatkannya. Pada soal TLM-2, siswa divergen menafsirkan kembali hasil yang diperoleh ke permasalahan awal dengan menuliskan kesimpulan penyelesaiannya dan tidak mengevalusi kesesuaian solusi ke dalam permasalahan awal karena sudah yakin dengan hasil jawabannya.

3. Literasi Matematis Siswa Asimilasi dalam Menyelesaikan Soal PISA Konten Space and Shape

Berikut ini adalah hasil jawaban siswa asimilasi dalam menyelesaikan soal Tes Literasi Matematis (TLM).

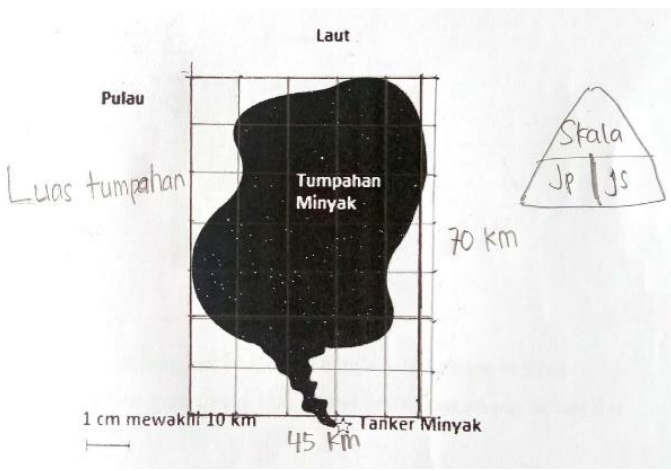

Gambar 7. Jawaban No 1 Siswa Asimilasi

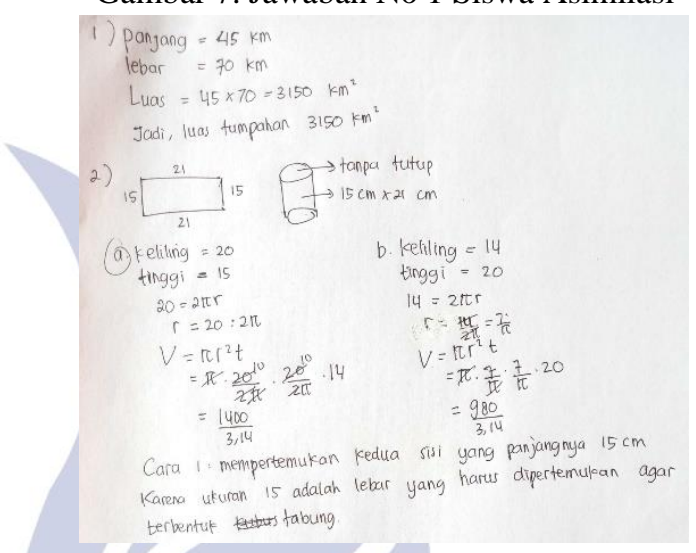

Gambar 8. Jawaban No 2 Siswa Asimilasi

Pada proses merumuskan (formulate) soal TLM-1, siswa asimilasi mengidentifikasi aspek matematika dan varibel penting yang terdapat dalam soal dengan menyebutkan informasi-informasi yang penting. Siswa asimilasi menyebutkan informasi-informasi tersebut ketika wawancara karena siswa asimilasi tidak menuliskan apa yang diketahuinya pada lembar jawaban. Siswa asimilasi menerjemahkan masalah tersebut ke dalam matematika dengan menggunakan pendekatan luas persegi panjang. Pada soal TLM-2, siswa asimilasi mengidentifikasi aspek matematika dan variabel penting dengan menyebutkan informasiinformasi penting pada soal. Siswa asimilasi menerjemahkannya ke dalam matematika dengan representasi bentuk persegi panjang dan tabung karena siswa asimilasi memahami soal TLM-2 berhubungan dengan volume tabung.

Pada proses menerapkan (employ) soal TLM-1, siswa asimilasi merencanakan dan menerapkan strategi untuk menyelesaikan soal dengan membuat persegi panjang yang mengelilingi daerah tumpahan minyak. Kemudian siswa asimilasi menggunakan aturan luas persegi panjang untuk menemukan solusi. Pada soal TLM-2, siswa asimilasi merencanakan dan menerapkan penyelesaiannya menggunakan rumus volume tabung. Siswa asimilasi menggunakan konsep volume tabung untuk menyelesaikan soal TLM-2 dengan menuliskan cara tahap demi tahap untuk menukan solusi. Hal ini sejalan dengan pendapat Knisley (2002) bahwa siswa 
asimilasi dapat menganalisis seuatu yang abstrak dan menyelesaikan masalah tahap demi tahap dan juga juga sejalan dengan Kolb (2005) bahwa siswa dengan gaya belajar asimilasi melibatkan pengalaman konseptualisasi abstrak.

Pada proses menafsirkan (interpret) soal TLM-1, siswa asimilasi menafsirkan kembali hasil matematis ke dalam permasalahan awal dengan menuliskan kesimpulan hasil akhirnya. Siswa asimilasi mengevaluasi kesesuaian jawabannya ke dalam permasalahan awal karena sebelumnya subjek asimilasi menemukan kesalahan. Pada soal TLM-2, siswa asimilasi menafsirkan kembali hasil matematis ke dalam permasalahan awal dengan menuliskan kesimpulan dan alasan dari hasil yang diperoleh. Siswa asimilasi juga mengevalusi kesesuaian jawabannya dengan menghitung kembali jawabannya. Menafsirkan kembali yang dilakukan subjek asimilisi sejalan dengan pendapat Knisley (2002) bahwa siswa asimilasi menyimpulkan pada akhir penyelesaian.

4. Literasi Matematis Siswa Konvergen dalam Menyelesaikan Soal PISA Konten Space and Shape

Berikut ini adalah jawaban siswa konvergen dalam menyelesaikan soal Tes Literasi Matematis.
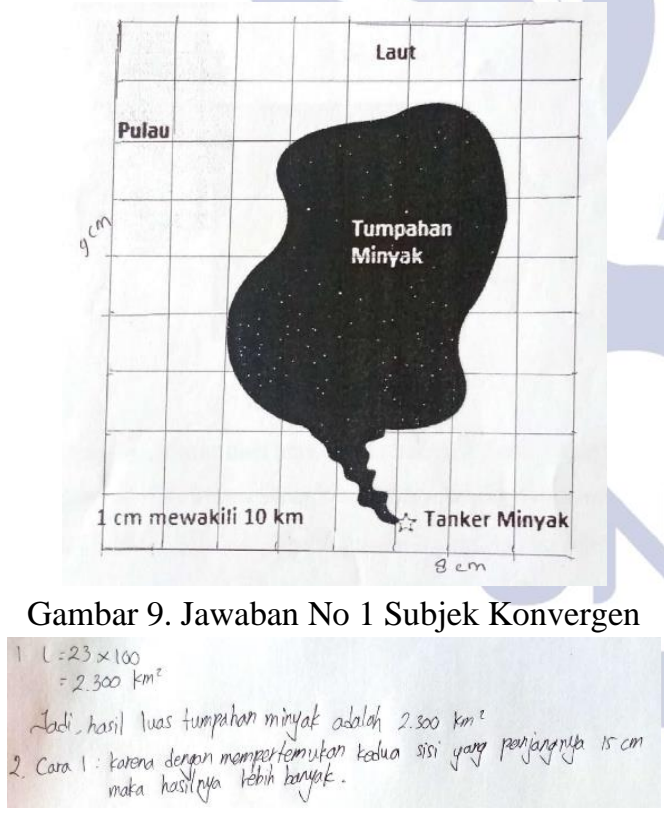

Gambar 10. Jawaban No 2 Subjek Konvergen

Pada proses merumuskan (formulate) soal TLM-1, siswa konvergen mengidentifikasi aspek penting dalam permasalahan dengan menyebutkan informasiinformasi penting dan menemukan tidak ada informasi yang kurang untuk menyelesaikannya. Siswa konvergen menyebutkan informasi-informasi tersebut ketika wawancara karena tidak menuliskan apa yang diketahuinya pada lembar jawaban. Siswa konvergen menerjemahkan masalah ke dalam matematika dengan membuat kotak-kotak persegi di atas daerah yang ditanyakan. Pada soal TLM-2, siswa konvergen mengidentifikasi aspek-aspek penting dari permasalahan dengan menjelaskan informasi penting yang digunakan dan meyakini tidak ada informasi yang kurang untuk menyelesaikannya. Namun, siswa konvergen tidak menerjemahkan masalah ke dalam bahasa matematika karena tidak memahami hubungan soal dengan matematika.

Pada proses menerapkan (employ) soal TLM-1, siswa kovergen merencanakan dan menerapkan strategi yang digunakan dengan membuat kotak-kotak persegi pada daerah tumpahan minyak. Siswa konvergen menggunakan aturan menentukan luas benda tidak beraturan dengan menghitung kotak yang terkena tumpahan minyak. Hal ini sejalan dengan pendapat Knisley (2002) bahwa siswa konvergen menggunakan teori dalam membuat keputusan. Pada soal TLM-2, subjek konvergen merencanakan dan menerapkan strategi dengan melakukan praktik langsung menggunakan kertas. Siswa konvergen menggunakan fakta hasil percobaan tersebut untuk menemukan solusi. Hal ini sejalan dengan Kolb (2005) bahwa siswa dengan gaya belajar konvergen melibatkan eksperimen aktif.

Pada proses menafsirkan (interpret) soal TLM-1 dan TLM-2, siswa konvergen manafsirkan kembali hasil matematis ke dalam permasalahan awal dengan menuliskan kesimpulan dari hasil perhitungannya dan tidak mengevaluasi kesesuaian solusi ke dalam permasalahan awal karena subjek konvergen sudah yakin dengan hasil jawabannya.

\section{PENUTUP}

\section{Simpulan}

Berdasarkan hasil dan pembahasan yang telah dijabarkan, maka diperoleh simpulan literasi matematis siswa dalam menyelesaikan soal PISA pada konten space and shape berdasarkan gaya belajar Kolb sebagai berikut.

1. Literasi siswa akomodasi dalam menyelesaikan soal PISA pada konten space and shape

Siswa dengan gaya belajar akomodasi melalui proses mengidentifikasi aspek penting dari permasalahan, menerjemahkan masalah ke dalam bahasa matematika, merencanakan dan menerapkan strategi untuk menemukan solusi, menggunakan konsep matematika dan perkiraan untuk menemukan solusi, menafsirkan kembali hasil perhitungannya dan mengevaluasi ksesuaian solusi yang diperoleh.

2. Literasi siswa divergen dalam menyelesaikan soal PISA pada konten space and shape

Siswa dengan gaya belajar divergen melalui proses mengidentifikasi aspek matematika yang penting dari soal, kurang tepat dalam menerjemahkan masalah ke 
dalam bahasa matematika, merencanakan dan menerapkan strategi menggunakan pendekatan dan percobaan langsung, menafsirkan kembali hasil perhitungannya dan tidak mengevaluasi kembali.

3. Literasi siswa asimilasi dalam menyelesaikan soal PISA konten space and shape

Siswa dengan gaya belajar asimilasi melalui proses mengidentifikasi aspek penting dari soal, menerjemahkan ke bahasa matematika dengan jelas, merencanakan dan menerapkan strategi untuk menemukan solusi, menggunakan konsep matematika dengan menuliskan tahap demi tahap, menafsirkan kembali hasil perhitungannya dan mengevaluasi kembali.

4. Literasi siswa konvergen dalam menyelesaikan soal PISA konten space and shape

Siswa dengan gaya belajar konvergen melalui proses mengidentifikasi aspek-aspek penting dalam permasalahan soal, kurang tepat dalam menerjemahkan ke dalam bahasa matematika, merencanakan dan menerapkan strategi untuk menemukan solusi, menggunakan konsep matematika dan percobaan langsung untuk menemukan solusi, menafsirkan kembali hasil matematis ke permasalahan awal dan tidak melakukan evaluasi kesesuaian jawaban.

\section{Saran}

Berdasarkan hasil penelitian dan simpulan yang telah dipaparkan, terdapat beberapa saran yang dapat peneliti sumbangkan kepada peneliti lain yang melakukan penelitian relevan sebagai berikut.

1. Pada penelitian ini, siswa dengan setiap gaya belajar Kolb memiliki perbedaan literasi matematis. Oleh karena itu, sebagai guru seharusnya dapat memahami perbedaan literasi matematis siswa sehingga dapat digunakan sebagai acuan untuk memberikan pembelajaran matematika yang berkaitan dengan literasi matematis.

2. Pada penelitian ini siswa tidak menuliskan yang diketahui dan yang ditanyakan pada lembar jawaban dikarenakan peneliti tidak menuliskan perintah harus menuliskan yang diketahui dan ditanyakan sehingga untuk menganalisis proses merumuskan hanya melalui metode wawancara saja, maka disarankan untuk peneliti lain dapat menuliskan perintah pada soal Tes Literasi Matematis untuk menuliskan apa yang diketahui dan ditanyakan agar proses merumuskan dapat dilihat dari hasil Tes Literasi Matematika dan wawancara.

3. Peneliti yang akan melakukan penelitian yang relevan dengan penelitian literasi matematis dalam menyelesaikan soal PISA dapat menggunakan konten lain dan meninjau dari gaya belajar yang lain.

\section{DAFTAR PUSTAKA}

Casidy, Simon. 2004. "Learning Style: An overview of theories, models, and measures". Educational Psychology, Vol.24 (4): hal 419-444.

Fatkhiyyah, I'aanatul, dkk. 2019. Kemampuan Komunikasi Matematika Siswa Ditinjau dari Perbedaan Gaya Belajar Menurut David Kolb. Jurnal Elemen. Vol.5 (2): hal 93-107.

Ghufron, M.Nur. 2012. Gaya Belajar. Yogyakarta: Pustaka Belajar.

Hertiandito, L.T. 2016. Kemampuan Literasi Matematika Siswa SMP pada Pembelajaran Knisley dengan Tinjauan Gaya Belajar. PRISMA, Prosiding Seminar Nasional Matematika. Hal 89-96.

Honey, Peter and Mumford, Alan. 2006. Kolb's learning Style.

http://www.clinteach.com.au/assets/LEARNING-

STYLES-Kolb-QUESTIONNAIRE.pdf (diakses 22 Januari 2017)

Johar, Rohman. 2012. Domain Soal PISA untuk Literasi Matematika. Jurnal Peluang. Vol.1 (1): hal 30-41.

Kolb, Alice Y dan Kolb, David A. 2005. The Kolb Learning Style Inventory-Version 3.12005 Technical Specifications. Case Western Reserve University. http://learningfromexperience.com/media/2010/08/Te ch_spec_LSI.pdf. (diakses 27 Januari 2017)

Knisley, Jeff. 2002. A four Stage Model of Mathematical Learning. Johnshon City: East Tennessee State University.

Mahdiansyah dan Rahmawati. 2014. "Literasi Matematika Siswa Pendidikan Menengah: Analisis Menggunakan Desain Tes Internasional dengan Konteks Indonesia1". Jurnal Pendidikan dan Kebudayaan. Vol. 20 (4): hal 455.

OECD. 2005. Learning a Living First Result of The Adult And Life Skills Survey. Paris: OECD Publishing.

OECD. 2013a. PISA 2012 Assessment And Analytical Framework Mathematics, Reading, Science, Problem Solving And Financial Literacy. Paris: OECD Publishing.

OECD. 2013b. PISA 2015 Draft Mathematics Framework. Paris: OECD Publishing

OECD. 2014. PISA 2012 Result: What Student Know and Can Do Student Performance In Matematics Reading and Science Volume 1. Paris: OECD Publishing

OECD. 2015. PISA 2015 Result in Focus. Paris: OECD Publishing. 
Permedikbud. 2015. Permendikbud No 23 Tahun 2015 Tentang penumbuhan Budi Pekerti. Jakarta: Kemendikbud. (Online) (http://simpuh.kemenag.go.id/regulasi/permendikbud 23 15.pdf diakses 20 Juni 2020)

Purnomo, Suryo dan Dafik. 2015. “Analisis Respon Siswa Terhadap Soal PISA Konten Space And Shape dengan Rasch Model". Makalah disajikan dalam Seminar Nasional Matematika dan Pendidikan Matematika UNY 2015, Yogyakarta, 30-31 Mei.

Sugiyono. 2009. Metode Penelitian Kuantitatif dan Kualitatif Dan R\&D. Bandung: Alfabeta

Syawahid, Putrawangsa. 2017. Kemampuan Literasi Matematika ditinjau dari Gaya Belajar. Beta Jurnal Tadris Matematika. Vol.10 (2): hal 222-240.

UNESCO. 2006. Understanding of Literacy. http://www.unesco.org/education/GMR2006/full/chap t6_eng.pdf (diakses 30 Januari 2017)

Wardhani, Isti Retno P. 2016. Tingkat Literasi Matematis Siswa Kelas X SMA Dalam Mengerjakan Soal PISA. Malang: Universitas Negeri Malang. Diakses pada tanggal 20 Februari 2017 dari pasca.um.ac.id.

Wilson, B.A. 2015. "Using Connectivism to Guide Information Literacy Instruction With Tablets". Journal Of Information Literacy. Vol. 9 (2): hal 27-36.

Zolghadri, Parvin, dkk. 2015. "On the Role of Learning Styles Component (Objective Experience, Reflective Observation, Abstract Conceptualization, and Active Experimentatition) on Student' Mathematics Performance)". American Journal of Educational Research. Vol.3 (9): hal 1142-1148.

Zulfidah, Alia. 2015. Profil Pemecahan Masalah Matematika Siswa SMP pada Materi Aritemtika Sosial Berdasarkan Gaya Belajar Kolb. (Skripsi tidak diterbitkan). Surabaya: Universitas Negeri Surabaya.

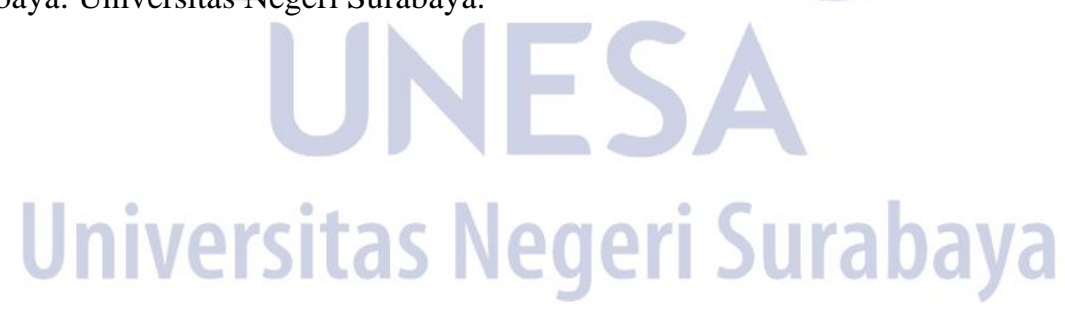

